\title{
The Role of the Shared Value "Justice" in the Management Approach of Educational Organizations of Rabbi Hirsch
}

Yochanan KIRSCHENBOIM ${ }^{1}$

\begin{abstract}
Rabbi Samson Hirsch, was born in Hamburg, Germany, on June 19, 1808, and died in Frankfurt am Main, Germany, on December 31, 1888. The years in which he was active were replete with far-reaching changes for European Jewry in general, and for German Jewry in particular.

His educational and literary writings made their mark on Jewish history, and that people admire him as a true revolutionary person and as someone who had managed to shape generations of students through his innovative methods in education and management of educational institutions.
\end{abstract}

Keywords: educational organizations, organizations management, shared values, community development

JEL classification: J24, J28, M14, M53

DOI: $10.24818 / \mathrm{RMCI} .2018 .4 .341$

\section{Introduction}

There are few people who succeed to make a difference in the people's life. The decisions, the values and commitment to the development of communities demonstrates the fact that rabbi Hirsch was such a leader, able to formulate a compelling vision and mission, based on religious values, to communicate it clearly and convincingly to the members of the Jewish community, to energize them into undertaking needed actions to apply in their life the principles he taught to them.

I also consider that he was also an entrepreneur and a manager due to the fact that he founded and managed two general schools, in which young Jews received a good education, with particular emphasis on training them both as good Jews and useful citizens. He established new principles in school management, which are quoted in his writings as the foundations of the Torah's laws. The purpose of this paper is to study the shared value Justice and demonstrate that it is valid in today's management of educational institutions in Israel.

His influence on the development of scientific Judaism was enormous throughout Germany, where it was called Neo-Orthodoxy. In my opinion, these are other proofs that rabbi Hirsch was a strong and highly influential religious values based leader and a visionary leader, able to develop a new and original approach as scientific Judaism. He also acted swiftly and wisely to apply the principles to the

Yochanan Kirschenboim, West University of Timisoara ${ }^{1}$ 
field of education and to the management of educational institutions, being himself a efficient and effective manager.

Hirsch's theory of education and management is based on three fundamentals: belief, comprehension, and action, that represent today the core of managing an organisation.

Belief, which is a fundamental concept for education, received renewed emphasis in Hirsch's thought, in that it is the foundation and starting point for developing one's world view. Without it, there can be no wisdom and no knowledge. Hirsch bases belief on the miraculous Divine intervention in historical events.

This belief is discovered through the experience of keeping the commandments, and through observation of God's world.

Comprehension is defined as religious comprehension accompanies the experience of belief, avoids the dangers of subjectivity, and provides rational meaning to its content. It takes on particular significance in times of crisis. Comprehension and study awaken our spirit to an active, living attitude toward Judaism, and an intellectual study of the commandments; it strengthens our relationship to them and shapes our education.

Religious action meaning duty, living "a life of duty." This consciousness comes from the willing acceptance of the authority of the Divine will, as reflected in the commandments and religious practices. Religious action has a decisive educational value for the one who acts. For the commandments are the expressions of ideals as life principles. The commandments represent a comprehensive educational approach. The commandments require the realization of "justice toward one's fellow man", toward creation as a whole, and toward the personality of he who carries them out. They demand a love for all, and they are an expression of mankind's memories, placing upon man the obligation to lift up and sanctify his inner life, so as to fulfill his duties in his external life.

\section{Fostering the Values Based Education}

Hirsch states in his writings that one of his educational fundamentals is the value of justice, which must be given expression in every educational institution. In the Eleventh Letter, Hirsch says: "The first prerequisite is justice! Respect every living thing about you and everything that is within yourself as the creation of your God. [Deem that which is his as having been placed in his hand by God or lawfully acquired by him before God.] Cede willingly to each that which it is justly entitled to call its own, [do not bring a curse upon the world]. Particularly, honor every human being as your equal, honor him, his invisible personality, by honoring his bodily envelope and his life... Give due respect to your word, the purest expression of your personality".

The commandments represent a comprehensive educational approach. The commandments require the realization of justice toward one's fellow man, toward creation as a whole, and toward the personality of he who carries them out. They

342 Review of International Comparative Management

Volume 19, Issue 4, October 2018 
demand a love for all, and they are an expression of mankind's memories, placing upon man the obligation to lift up and sanctify his inner life, so as to fulfill his duties in his external life.

In his Tenth Letter, rabbi Hirsch states about the role of justice as a moral value, "thus we have... three fundamental concepts; namely justice, love and education".

The first concept is justice; that is, consideration for everything as a creature of God, regard of every possession as willed by God's decree, and the viewing of every system of law and order as having been ordained by God; and the fulfillment of all the claims each has upon us.

Tzedaka is presupposed by tzedek (justice), and leads toward it. Used referring to God, it is always a deed of benevolence. Referring to man, it is benevolence towards the receiver, duty toward God. For God placed every man, with every grain of his spiritual and material powers, in the service of justice. $\mathrm{He}$ is only given them to use them to further the tzedek-well-being of the world about him. Every such contribution is tzedaka, so that tzedaka is the total sum of a life lived faithfully to duty, of which mishpat is but the negative side, not doing wrong, whereas tzedaka is the positive realization of what is good.

In his view, justice and righteousness are absolute values, as are truth and beauty. We must therefore maintain them, not merely because the Holy One commanded us regarding them. On the contrary, it is because they are moral values, that the Holy One, Blessed be $\mathrm{He}$, preserves them and demands them of His creatures (Heinman, Reasons for the Commandments, p. 99.

Consequently, Rabbi Hirsch concludes that humans know what is just from the voice of conscience that God has instilled in their hearts, and that fear of God makes acts of injustice impossible. In "Fundamentals of Education", p. 46, Rabbi Hirsch provides additional religious arguments for justice and morality, when he writes that "... we must do that which is good, as the commandment of God. We must ensure justice and morality, because God has so commanded us; at his command, we must conduct ourselves as creatures made in God's image, behaving with loving kindness and mercy, truth and faith, tolerance and forgiveness. We must have consideration for others, and remove from before our eyes those feelings that mask the TzelemElokim, the image of God. We must live a life of morality and justice, be holy and merciful to all of God's works. We must be fair as human beings. This is our message for mankind as a whole, and in the first instance we must carry it out toward ourselves."

Hirsch argued that the conscience was that inner voice that God implanted within man, so that he should carry out the task of justice in his life. Hirsch went further: the conscience is that inner revelation of God within the soul, whose purpose is to guide man so that he takes responsibility in relation to the people around him. Hirsch claims that there is a universal mission, to bring the world back to an awareness of justice and rights. This universal mission imposes a duty to instill the principles of justice and an awareness of human rights. [as will appear below]. In the 11th letter: 
"... God is the source of truth and justice, and the voice of justice leads you to recognize that which is good and right in the eyes of God. That which is truthful and just is that which is consistent with the will of God, and truth and justice are the foremost part of God's revelation within your inner soul. This is the voice that demands of you that your actions between just, and for you to know regarding all those who surround you - what you owe them, you must know all of those around you, and yourself, exactly as God knows them and you. And if, instead of guiding you toward justice, your unfettered will let go of the reins of responsibility in you, and you no longer listen to the voice within your soul, then you will hasten your decline to a spiritual nadir, spiritual suicide, and abandonment of your duty..."

Thus justice is the sum total of your life, as it is the sole concept which the Torah serves to interpret .Mishpatim are justice in deed and word towards men. Chukim, justice towards the beings subordinated to you - plants, animals and the earth - as well as your own body, mind and spirit and their forces. Mitzvoth, justice towards God, Who not only demands that you respect His world and that you do not impair the creatures about you, but Who has also created you for love and that you many become a blessing for the world. Edoth, justice towards God, yourself, Israel, and mankind. Toroth, justice of your thoughts towards reality, and of your feelings towards your destiny, truth and virtue. Avodah, training of yourself in this justice.

In summary, let us more sharply define the relationship between the terms Tzedek, Tzedaka and Mishpat, in Hirsch's thought. Tzedek is the ideal. Tzedaka is the Divine or human action that brings mankind closer to the Tzedek ideal. And Mishpat means the imposition of order, Mishpat only serves to maintain the status quo, or return property to its owner. One who combines mishpat and tzedaka within his life has certainly fulfilled his obligation. These are the ethical fundamentals on which to build an ethic for the appropriate relationship of man with those who are with him. And this is part of the totality of life.

\section{The Educational Institutions as Values Promoters}

Within the educational institution, it must be remembered that justice is central to our lives. Therefore, the school strategy should be based on justice. Every education system is founded on justice. The existence and function of a school following the "Torah with DerekhEretz" approach must, of necessity, lead to justice. I consider that the slogan of "Torah with DerekhEretz" forms the basis for the whole of Hirsch's philosophy and ideas, and in it he expresses his perspective regarding the relationship between Torah and life, between the spiritual and the material, between the Creator and His creations. Hirsch emphasizes the fact that God is not just the Giver of the Torah, but also the Creator of the world, who put into place the laws of nature. God speaks to man from within nature and from within history, and by considering them both nature and history, man can learn about his Creator. However, it is not sufficient to observe nature alone. Man is also

342 Review of International Comparative Management

Volume 19, Issue 4, October 2018 
called upon to act and to achieve in his lifetime. Hirsch rejects ascetism and detachment from society, and shows that it is actually through a life that is healthy and economically well-based that one can sanctify the material world, and achieve the higher level of a full, complete Torah lifestyle (Heinemann, 1956).

Observing and understanding nature and all that is around you, is a step towards finding appropriate goals for your own life and if you are a manager for your organizations. The educational institutions are at the basis of promoting the soundest values for a community. Based on analysis than, one is able to identify several solutions solutions for acting within the surrounding environment in order to achieve both long-term and short-term individual and organizational set goals.

That is actually the planning process taking into account the material goals achievement both effectively (life that is healthy) and efficiently (life economically well based), and also the achievement of spiritual goals effectively (sanctifying the material world) and efficiently (achieving the higher level of a complete Torah religious based lifestyle).

Furthermore, Judaism is a religion that encompasses all aspects of life. The Torah is a Torah of life, and its demands are not bounded within the synagogue or study hall. There is no such concept as "secular life"; the Torah accompanies and commands the Jew in anything to which he/she does. "Through all your paths shall you know Him" - that means that along whatever path that the Jew walks as a Jew, he can and must live a full Torah life.

The immediate practical implication of this conception for Hirsch's time (in the 19th century) is that in an era of emancipation, modernization of the society (German, in his case) one must abandon the life of the ghetto, accepting the conditions of modern life as a positive DerekhEretz, and live a Torah life under those conditions. This is not to be viewed as a concession, or out of utilitarian considerations. Hirsch argued that this should be done out of an ideal, an understanding that within the conditions of modern life there is the inherent potential for the development of a full Torah life that is more all-encompassing than under the conditions of the ghetto.

He provide a clear path to achieve this ideal, fulfilling also the role a leader has for guiding his followers towards the realization of their common vision. Applying these principles in an educational organization, Rabbi Hirsch also provided practical solutions to planning, organizing, motivating employees and students and controlling, in order to achieve the effective and efficient functioning of the school he founded and managed.

The innovation in Hirsch's thought lies, therefore, in the centrality of the concept of Torah with DerekhEretz. From his point of view, this is the Judaism's eternal message, the fundamental on which everything else is dependent. Indeed, given the background of his times, Hirsch's words also addressed the challenges of modern time, and provided a valid alternative path to young people wavering between a life of Torah and the acquisition of a modern profession. Notwithstanding this, Hirsch does not see his concept merely as a means of saving 
German Jewry. Rather, he saw it as the essence of Judaism as a whole, something reflected in every chapter of the Torah and every statement of the Sages.

Given this platform, Hirsch was able to offer a description of the consummate Jewish individual, living within the non-Jewish world. All men are created in the image of God, and as a result all men have the potential of achieving the highest levels of human moral perfection. The Jew is, first and foremost, a human being, and so - even before being a "Jew," he has to be a "human," that is, he/she must acquire the values of pure humanity (Heinemann, 1956).

I consider that from a managerial point of view, Derekheretz is a way to build and manage an organization as an open system, strongly connected to its external environment. The organization being formed by individuals and groups in an orderly manner and functioning towards the accomplishment of a common set of goals, provides a framework for the individual to act for achieving his role in the world and also to contribute to the world becoming a better place. Consequently, managerially speaking, Derekheretz represents a multiple stakeholders approach to managing and organization, based on a spiritual approach, offered by the foundations of Jewish religion.

Within the school there are rules and directives whose basis is justice as defined by Rabbi Hirsch. These are the following five:

a) Loyalty to duty and to the school's rules goes to the very definition of justice.

b) The teacher's conscience is his own true justice.

c) Neatness and cleanliness within the school - these go to the definition of justice, from the point of view of God's laws.

d) The initial, inner voice that is heard by every individual, and certainly by the educators - this underlies the ideas of truth and justice, and so every teacher and his personal right to liberty must be respected.

e) The right of every individual, without distinction, to choose for himself leads to justice. And so emphasis needs to be placed on the quality of teaching, and not merely on quantity.

He formulated also eight principles for school management that derive from the value of justice. These are the following:

a) One must always consult with experts and subject instructors, since they are considered to be objective.

b) On any matter that is subject to dispute, it is the institution's general meeting that will make the determination.

c) The teachers and the school administration alike need to pay heed to external presentation, walking upright and looking directly at both students and parents. Such an approach will attest to one's being an honest, truthful individual who is considerate of those around him.

d) The principal serves as a guide for the teachers, and so the whole of the educational and teaching staff need to obey his rules. 
e) Teachers, and the school as a whole, need to undergo self-education and character development. This is one of the obligations of every educator in the school.

f) Within the school, there is a need for beauty, order and organization.

g) A school must have the newest, most advanced equipment.

h) The best form of publicity for recruiting students (clients) is to go from door to door, using the word of mouth approach.

In keeping with the value of justice, all teachers need to know the school's goals and values, to be part of it, and to be committed to respecting and applying the school's principles in their work.

The norms established in the school are what will determine the school's status according to rabbi Hirsh. It is well known that there are differences in ethics, depending on the particular place, society or time. It is therefore necessary that, within the school, all of its staff maintain and be in wholehearted agreement with the ethics and values established for the school, rather than shifting in line with the whims of social or cultural change.

The students should be educated toward truth and justice. One should respect the individual student's nature, bringing him in and encouraging him to develop his personal capabilities. Hence, every educator needs to aspire to the highest level of quality in his teaching.

The value of justice teaches us that man is innately pure in spirit and in morality, similar to God, and so must preserve this purity at school and in all educational frameworks. This needs to be reflected in the fact that one must treat the students individually, and be their "friend." One must speak to the students in their language, and take interest in them. One should never shout at the students.

Rabbi Hirsch considered that every educator needs to serve as a role model, and to this end the principal needs to ensure that professional training be provided within the school, with new or current things being taught, so that the teaching staff remains relevant to the needs of the students. The school's principal needs to ensure a constant improvement in the quality of teaching and professional development of his teachers, through in-service training within the institution that meets the needs of the teachers as professionals, and which is based on the fundamental needs and values of the school as a systemic whole.

The school principal also needs to ensure that the teaching staff is provided with an annual vacation for resting, for individual introspection through contemplating God's world, and for improving their capacity to serve as a role model, in order to communicate the values to the students in the most honest and just manner possible. The educator needs to aspire to be a personality, and indeed, this should also be the aspiration of the students themselves. The teacher should serve as a role model, both within the school and outside it. The work of education takes place constantly, at all hours of the day, every day.

A school, in which "justice" is one of its primary goals and values, has the responsibility to teach that it is man's destiny to live a life of action, within all 
areas of the life of society. Expanding the means to do so will correspondingly increase the opportunities to achieve one's goals.

The school's principal needs to transmit his knowledge to the teaching staff. He must also demand of all the staff that they stand by their own actions and be in agreement with the content being taught, so as to be able to properly represent the school.

The principal shapes the educational policy along with the teaching staff. It is he who initiates changes and promotes new educational projects, fundamentals and values, and it is he who delegates his authority and passes responsibility to the teachers. Involvement of the teaching staff in the administration of the school intensifies their responsibility toward implementation, increases the teachers' satisfaction with their work, enhances social cohesion, and raises the morale of the staff.

\section{Conclusions}

The value of justice teaches that all those within the school's walls have an obligation to preserve the school's property. Any negative or problematic trait in a student - or, for that matter, in a teacher - should be transformed into a positive one, rather than merely being criticized. The emphasis should be on actions, not on words, and the recommended method is through the study of new things. Constant learning prevents gossip and slander. Through study and in-service training, the teachers will find themselves occupied with their own affairs, rather than keeping an eye on their colleagues.

When the underlying basis for teaching is to educate the students and the teaching staff toward morality and ethics, this has an influence on the whole of the school's daily routine and on its future; it differentiates it from the rest, and turns it into a leader.

The value of justice serves as the "glue" that holds the school together, particularly in difficult times of uncertainty and competition with other schools. The service and audit process within the institution is to monitor the justice and honesty of the teaching staff. Every educational process is checked within the framework of the social system: is the action consistent with the orderly conduct of society, and with the values and goals established initially by the staff of the school?

After any unusual event that takes place within the school, it should be reviewed in light of the values and principles that have been set - were they appropriate, or was there some deviation? One should constantly aspire to remember the principles of "Torah with DerekhEretz" and "Train a lad in the way he ought to go," which Hirsch set as the foundation for the education system.

Discussing his approach to educational methods, I appreciate that in his view, there is no contradiction between the authoritarian conception of education and the free encouragement of the pupil. His reason is that is within the power of an unfettered education to lead to an educational process based on the 
internalization and identification of man's will with that of God. Consequently, rabbi Hirsch calls for the use of methods that were not customary in traditional education during his time, such as: the exercise of free will, esthetic satisfaction, man's observation of himself and observations of the meaning of life's phenomena. The educator must respect the nature of the child, drawing him near and fostering the characteristics of his personality.

In conclusion, the value of justice is a fundamental value in the management of educational institutions in the state of Israel in our time.

\section{References}

Heinemann, Y. (1956). Studies about Hirsch, Sinai Publishing.

Heinemann, Y. (1956). Reasons for the Religious Commandments in the Israeli Literature, Jerusalem.

Hirsch, S. R. Fees of North, in the website: www.HebrewBooks.org

Hirsch, S. R. Horeb, in the Website: www.HebrewBooks.org

Hirsch, S. R. Interpretation and Translation for German of Five Books of Moses. www.HebrewBooks.org

Hirsch, S.R. Nineteen Letters (Feldheim),

Hirsch, S. R. Shabbat for Israel, in the website: www.HebrewBooks.org

Hirsch, S. R. Shabbat Pleasure, in the website: www.HebrewBooks.org

Hirsch, S. R., Fundamentals of Education, www.HebrewBooks.org

Hirsch, S. R. Writings of the Rabbi of the Israeli Year 1', in the website: www.HebrewBooks.org

Hirsch, S. R. His Writings, www.HebrewBooks.org. 